\title{
Article \\ Effect of Nitrogen Addition on Soil Microbial Functional Gene Abundance and Community Diversity in Permafrost Peatland
}

\author{
Xiuyan Ma ${ }^{1}$, Yanyu Song ${ }^{1, *}$, Changchun Song ${ }^{1}$, Xianwei Wang ${ }^{1}$, Nannan Wang ${ }^{1}$, Siqi Gao ${ }^{1,2}$, \\ Xiaofeng Cheng ${ }^{1,3}$, Zhendi Liu ${ }^{1,2}$, Jinli Gao ${ }^{1}$ and $\mathrm{Yu}_{\mathrm{Du}}{ }^{1}$ \\ 1 Key Laboratory of Wetland Ecology and Environment, Northeast Institute of Geography and Agroecology, \\ Chinese Academy of Sciences, Changchun 130102, China; maxiuyan@iga.ac.cn (X.M.); songcc@iga.ac.cn (C.S.); \\ wangxianwei@iga.ac.cn (X.W.); wangnannan@iga.ac.cn (N.W.); gaosiqi@iga.ac.cn (S.G.); \\ c4x4yf@163.com (X.C.); liuzhendi20@mails.ucas.ac.cn (Z.L.); gaojinli@iga.ac.cn (J.G.); duyu@iga.ac.cn (Y.D.) \\ 2 University of Chinese Academy Sciences, Beijing 100049, China \\ 3 Heilongjiang Province Key Laboratory of Geographical Environment Monitoring and Spatial Information \\ Service in Cold Regions, Harbin Normal University, Harbin 150025, China \\ * Correspondence: songyanyu@iga.ac.cn
}

check for updates

Citation: Ma, X.; Song, Y.; Song, C.; Wang, X.; Wang, N.; Gao, S.; Cheng, X.; Liu, Z.; Gao, J.; Du, Y. Effect of Nitrogen Addition on Soil Microbial Functional Gene Abundance and Community Diversity in Permafrost Peatland. Microorganisms 2021, 9 , 2498. https://doi.org/10.3390/ microorganisms 9122498

Academic Editor: Elisa Gamalero

Received: 29 October 2021

Accepted: 1 December 2021

Published: 2 December 2021

Publisher's Note: MDPI stays neutral with regard to jurisdictional claims in published maps and institutional affiliations.

Copyright: (c) 2021 by the authors Licensee MDPI, Basel, Switzerland. This article is an open access article distributed under the terms and conditions of the Creative Commons Attribution (CC BY) license (https:/ / creativecommons.org/licenses/by/ $4.0 /)$.

\begin{abstract}
Nitrogen is the limiting nutrient for plant growth in peatland ecosystems. Nitrogen addition significantly affects the plant biomass, diversity and community structure in peatlands. However, the response of belowground microbe to nitrogen addition in peatland ecosystems remains largely unknown. In this study, we performed long-term nitrogen addition experiments in a permafrost peatland in the northwest slope of the Great Xing'an Mountains. The four nitrogen addition treatments applied in this study were $0 \mathrm{~g} \mathrm{~N} \cdot \mathrm{m}^{-2}$.year ${ }^{-1}(\mathrm{CK}), 6 \mathrm{~g} \mathrm{~N} \cdot \mathrm{m}^{-2} \cdot \mathrm{year}^{-1}(\mathrm{~N} 1), 12 \mathrm{~g} \mathrm{~N} \cdot \mathrm{m}^{-2} \cdot \mathrm{year}^{-1}(\mathrm{~N} 2)$, and $24 \mathrm{~g} \mathrm{~N} \cdot \mathrm{m}^{-2} \cdot \mathrm{year}^{-1}(\mathrm{~N} 3)$. Effects of nitrogen addition over a period of nine growing seasons on the soil microbial abundance and community diversity in permafrost peatland were analyzed. The results showed that the abundances of soil bacteria, fungi, archaea, nitrogen-cycling genes (nif $\mathrm{H}$ and b-amoA), and morA increased in N1, N2, and N3 treatments compared to CK. This indicated that nitrogen addition promoted microbial decomposition of soil organic matter, nitrogen fixation, ammonia oxidation, nitrification, and methane production. Moreover, nitrogen addition altered the microbial community composition. At the phylum level, the relative abundance of Proteobacteria increased significantly in the N2 treatment. However, the relative abundances of Actinobacteria and Verrucifera in the N2 treatment and Patescibacteria in the N1 treatment decreased significantly. The heatmap showed that the dominant order composition of soil bacteria in N1, N2, and N3 treatments and the CK treatment were different, and the dominant order composition of soil fungi in CK and N3 treatments were different. The N1 treatment showed a significant increase in the Ace and Chao indices of bacteria and Simpson index of fungi. The outcomes of this study suggest that nitrogen addition altered the soil microbial abundance, community structure, and diversity, affecting the soil microbial carbon and nitrogen cycling in permafrost peatland. The results are helpful to understand the microbial mediation on ecological processes in response to $\mathrm{N}$ addition.
\end{abstract}

Keywords: nitrogen input; soil microbial functional gene abundance; soil microbial community diversity; permafrost peatland

\section{Introduction}

Nitrogen $(\mathrm{N})$ is the primary restricting factor for plant growth in terrestrial ecosystems [1]. Since the industrial revolution, $\mathrm{N}$ deposition has increased significantly [2,3]. The current global $\mathrm{N}$ deposition ranges from 0.05 to $2 \mathrm{~g} \mathrm{~N} \cdot \mathrm{m}^{-2} \cdot$ year $^{-1}$ [4], and it is expected to increase 2.5-fold by the end of the current century [5]. A continuous rise in $\mathrm{N}$ deposition has become a global eco-environmental concern [6]. $\mathrm{N}$ deposition is the most vital driving factor for carbon sink in China's terrestrial ecosystem [7]. The aggravation of $\mathrm{N}$ deposition has resulted in soil acidification [8]. This, in turn, has altered the composition and diversity 
of plants and microorganisms $[9,10]$, as well as the soil carbon (C) and $\mathrm{N}$ biogeochemical cycles [11], influencing the ecosystem stability. Soil microbes are involved in different biogeochemical cycles, including $C$ and $N$ mineralization $[12,13]$, and they play a crucial role in ecological functioning of the ecosystem. Bacterial and fungal communities are vital components of the soil microbial community and play a crucial role in ecological functioning of ecosystem [14]. The abundance of functional genes encoding key enzymes has gained substantial attention over the recent years. The altered abundance of crucial enzymes could unravel the soil $\mathrm{N}$ transformation response mechanism to $\mathrm{N}$ addition [15]. Previous studies have shown that $\mathrm{N}$ addition could remarkably alter the microbial abundance and community composition by enhancing $\mathrm{N}$ availability in the soil, as well as the relationship between above- and belowground ecosystems in peatlands $[16,17]$. Understanding how microbial abundance and community operate in ecological and biogeochemical processes is essential to understand the mechanisms underlying microbe-driven changes in soil C and $\mathrm{N}$ cycling under $\mathrm{N}$ addition.

The response of soil microbe to $\mathrm{N}$ addition depends on the microbial species, the $\mathrm{N}$ treatment duration and amount, and the ecosystem type. The fungal community is more sensitive than the bacterial community to $\mathrm{N}$ deposition [18]. A low amount of $\mathrm{N}$ addition could increase bacterial and fungal abundance, but a high amount of $\mathrm{N}$ addition could decrease bacterial abundance [19]. Mineral N addition decreases soil bacterial diversity, while organic $\mathrm{N}$ addition increases soil bacterial diversity $[20,21]$. As shown previously, short-term $\mathrm{N}$ addition increased the richness and Shannon and McIntosh indices of bacterial and fungal communities in the paddy soil [22]. However, long-term $\mathrm{N}$ addition decreased bacterial richness by changing soil $\mathrm{pH}$ and plant composition in temperate steppe grassland and increased fungal diversity and relative abundance of complex carbohydrate-decomposing bacterial and fungal groups in alpine meadows [23]. Biogeochemical processes and ecosystem functions are directly associated with altered abundance, diversity, and composition of soil microbial communities [18,24]. To predict the responses of ecosystem functions to altered $\mathrm{N}$ element levels, it is essential to understand how $\mathrm{N}$ addition shapes microbial communities and how these shifts are linked to crucial processes of element cycling. However, the effects of long-term $\mathrm{N}$ addition on soil microbial abundance, community composition, and diversity in permafrost peatlands remain ambiguous. Thus, the responses and potential mechanisms of microbial community structure to $\mathrm{N}$ addition need to be explored by more field experiments due to limited data and inconsistent responses with other soil.

Most permafrost peatlands are located at high latitudes. These peatlands are often $\mathrm{N}$-limited, due to slow decomposition in cold, acidic, and frequently waterlogged soils, along with more $\mathrm{N}$ stored in peatland soil tightly bound with organic matter, compared with other ecosystems $[25,26]$, which are more sensitive to environmental changes. A high climatic temperature promotes soil organic matter mineralization through microbial decomposition, releasing available $\mathrm{N}$ that could be absorbed and utilized by plants [27]. The projected $3^{\circ} \mathrm{C}$ rise in temperature will increase $\mathrm{N}$ mineralization by $7 \mathrm{~g} \mathrm{~N} \cdot \mathrm{m}^{-2}$. year $^{-1}$, whereas a $7{ }^{\circ} \mathrm{C}$ rise in temperature will increase $\mathrm{N}$ mineralization by $9.4 \mathrm{~g} \mathrm{~N} \cdot \mathrm{m}^{-2} \cdot$ year $^{-1}$ in high-latitude regions [28]. Thus, global warming and $\mathrm{N}$ deposition can alleviate the existing $\mathrm{N}$ limitation and increase $\mathrm{N}$ availability in peatlands [29]. However, only a few studies have explored the response of the soil microbial function and community diversity to altered levels of $\mathrm{N}$ elements in permafrost peatland, and the relationship between soil microbial community composition and environmental factors remains unclear. Longterm field studies are scarce, thus hindering determination of the extent and direction of the impact. Thus, it is important to investigate the responses of the soil microbial communities to $\mathrm{N}$ addition in permafrost peatlands. In this study, a long-term $\mathrm{N}$ addition experiment was performed in the northwest slope of the Great Xing'an Mountains. After nine growing seasons, we collected soil samples and applied real-time PCR (RT-PCR) and high-throughput sequencing techniques to determine the change in the soil microbial functional gene abundance and community diversity under four levels of $\mathrm{N}$ addition. 
RT-PCR was used to detect the abundances of bacteria, fungi, archaea, nif $\mathrm{H}$, bacteria-amoA (b-amoA), nirK, nirS, mcrA, and pmoA genes. Illumina Miseq sequencing of bacterial 16S rRNA and fungal ITS genes was used to assess the effect of $\mathrm{N}$ addition treatments on the soil bacterial and fungal community composition and diversity. In this study, we focused on two aspects: (1) the response of soil microbial abundance to $\mathrm{N}$ addition in N-limited peatland; (2) the relationship of soil substrate properties with the composition and diversity of microbial communities under $\mathrm{N}$ addition. We hypothesized that $\mathrm{N}$ addition would increase soil microbial abundance and community diversity in permafrost peatland by increasing soil nutrient contents, and that the response would be greater than other soil systems due to stronger $\mathrm{N}$ limitation.

\section{Materials and Methods}

\subsection{Site Description}

The study was conducted in a permafrost peatland located at the northwest slope of the Great Xing'an Mountains in Northeast China $\left(52^{\circ} 94^{\prime} \mathrm{N}, 122^{\circ} 86^{\prime} \mathrm{E}\right)$. The active layer is $50 \mathrm{~cm}$ to $60 \mathrm{~cm}$ above the permafrost layer. The mean annual air temperature is $-3.9^{\circ} \mathrm{C}$, and the mean annual precipitation is $450 \mathrm{~mm}$, with $45 \%$ falling as rain from July to August [30]. The dominant plant species are Eriophorum vaginatum L., Vaccinium uliginosum L., Chamaedaphne calyculata L. Moench, Ledum palustre L., and Sphagnum spp.

\subsection{Experimental Design and Sampling}

The experiment was established in autumn 2011. A total of 12 plots were established; each plot was $2 \mathrm{~m} \times 2 \mathrm{~m}$ and separated by a $1 \mathrm{~m}$ buffer to prevent increased horizontal movement and lateral loss of $\mathrm{N}$. This experiment entailed a total of four $\mathrm{N}$ addition treatments: $0 \mathrm{~g} \mathrm{~N} \cdot \mathrm{m}^{-2} \cdot$ year $^{-1}(\mathrm{CK}), 6 \mathrm{~g} \mathrm{~N} \cdot \mathrm{m}^{-2} \cdot$ year $^{-1}(\mathrm{~N} 1), 12 \mathrm{~g} \mathrm{~N} \cdot \mathrm{m}^{-2} \cdot$ year $^{-1}$ (N2), and $24 \mathrm{~g} \mathrm{~N} \cdot \mathrm{m}^{-2} \cdot$ year $^{-1}(\mathrm{~N} 3)$; each treatment was applied to three replicated plots. For each $\mathrm{N}$ addition treatment, $\mathrm{NH}_{4} \mathrm{NO}_{3}$ was first dissolved in $1 \mathrm{~L}$ of surface water and then sprayed evenly on the target area. The same amount of surface water without $\mathrm{NH}_{4} \mathrm{NO}_{3}$ was sprayed in the CK treatment. The treatments were applied during the growing season (from May to September) of 2012 to 2020. The soil samples were sampled from 0-20 cm below the plant litter layer from each plot on 13 August 2020, and five sampling points were collected with a soil drill from each plot and mixed to form a composite sample. The soil samples were divided into subsamples for further analysis. One of the subsamples was stored at $-80{ }^{\circ} \mathrm{C}$ to determine the functional gene abundance and community diversity of soil microbes. The second soil subsamples were stored at $4{ }^{\circ} \mathrm{C}$ for dissolved organic carbon (DOC), ammonia nitrogen (AN), and nitrate nitrogen (NN) content determination. The remaining soil subsamples were air-dried to determine the soil total carbon (TC), total nitrogen (TN), and total phosphorus (TP) content, as well as soil $\mathrm{pH}$.

\subsection{Microbial Functional Gene Abundance and Community Diversity Analysis}

DNA from $0.3 \mathrm{~g}$ of soil samples was extracted using a FastDNA ${ }^{\circledR}$ Spin Kit for Soil (MPbio, Irvine, CA, USA), according to the manufacturer's instructions. The extracted DNA was stored at $-80^{\circ} \mathrm{C}$ prior to functional gene and sequencing analysis. The abundances of bacteria, fungi, archaea, nif $\mathrm{H}, \mathrm{b}-a m o \mathrm{~A}, n i r \mathrm{~K}, n i r \mathrm{~S}, m c r \mathrm{~A}$, and pmo $\mathrm{A}$ genes were determined by RT-PCR, which was performed on the ABI StepOne instrument (Applied Biosystems, Beverly, MA, USA) and SYBR green dye. RT-PCR analysis for each soil sample was replicated three times. RT-PCR primers for target gene amplification and the detailed procedure are presented in Table S1. The $25 \mu \mathrm{L}$ PCR reaction mixture contained $12.5 \mu \mathrm{L}$ of SYBR Buffer (TaKaRa, Beijing, China), $0.4 \mu \mathrm{L}$ of each primer $(10 \mu \mathrm{M}), 0.5 \mu \mathrm{L}$ of ROXII (TaKaRa, Beijing, China), $0.88 \mu \mathrm{L}$ of $3 \%$ BSA, $0.63 \mu \mathrm{L}$ of DMSO, and $10 \mathrm{ng}$ of template DNA. For standard curve generation, the amplicon products of phylogenetic and functional markers were purified using a Cyclic Purification Kit (OMEGA Bio-Tek, Norcross, GA, USA), ligated to the vector pMD18-T (TaKaRa, Beijing, China), and then transformed into TOP10 Escherichia coli competent cells. The plasmids were extracted using the Plasmid 
Mini Kit (OMEGA Bio-Tek, USA/Georgia). The specificity of plasmids was determined through the Basic Local Alignment Search Tool [31], and the plasmid concentration was determined using a Nanodrop 2000 (Thermo, Waltham, MA, USA). The standard curve was obtained by continuous dilution of known copy number plasmids.

For microbial community analyses, the V3-V4 region of the $16 \mathrm{~S}$ rDNA gene was amplified with primers $338 \mathrm{f}\left(5^{\prime}-\right.$ ACTCCTACGGGAGGCAGCAG-3') and $806 \mathrm{r}\left(5^{\prime}-\mathrm{GGACTACHV}\right.$ GGGTWTCTAAT-3') [32], and the ITS1 region of the $18 \mathrm{~S}$ rDNA gene was amplified with primers ITS1f $\left(5^{\prime}-\right.$ CTTGGTCATTTAGAGGAAGTAA-3') and ITS2r (5'-GCTGCGTTCTTCA TCGATGC $-3^{\prime}$ ) [33] under the following conditions: initial denaturation at $95{ }^{\circ} \mathrm{C}$ for $3 \mathrm{~min}$, followed by 35 cycles of $95{ }^{\circ} \mathrm{C}$ for $30 \mathrm{~s}, 55^{\circ} \mathrm{C}$ for $30 \mathrm{~s}$, and $72{ }^{\circ} \mathrm{C}$ for $45 \mathrm{~s}$, and a final extension at $72{ }^{\circ} \mathrm{C}$ for $10 \mathrm{~min}$. The PCR products were purified using a Qia quick PCR Purification kit (Qiagen, Dusseldorf, Germany). The PCR products of different samples were pooled and sequenced on the Illumina MiSeq platform (Illumina, San Diego, CA, USA). Raw sequences of different samples were separated using barcodes, and up to one mismatch was allowed while using the FLASH tool [34]. The quality of the sequence was strictly filtered using the QIIME tool, and Btrim [35] was employed for quality trimming and removing the low-quality regions $(Q<20)$, the sequences $<150$ bp in length, and singletons. The chimeric sequences were detected and removed using VSEARCH [36] to obtain sequences. OTUs were classified using UCLUST at a 97\% similarity level, and singletons were removed. Rarefaction analysis was conducted using the originally detected OTUs [37]. The taxonomic assignment was conducted using the Ribosomal Database Project (RDP) classifier [38] with minimal 80\% confidence estimates. The RDP classifier was used to assign taxonomic data to each representative sequence. All sequences from this study were deposited at NCBI with accession number PRJNA735903.

\subsection{Soil Chemical Analysis}

The soil total carbon (TC) content was determined via the dry combustion method with the multi N/C 2100 analyzer (Analytik Jena, Jena, Germany). Dissolved organic carbon (DOC) in the soil was determined, as per the method described by Ghani et al. [39]. Total N (TN) and total phosphorus (TP) in the soil samples were digested using sulfuric acid and later quantified through an AA-3 continuous flow analyzer (Seal Analytical, Germany/Norderstedt). Soil ammonium N (AN) and nitrate N (NN) were extracted with $2 \mathrm{~mol} \cdot \mathrm{L}^{-1} \mathrm{KCl}$ and then analyzed with the AA-3 continuous flow analyzer (Seal Analytical, Norderstedt, Germany). Soil pH values were analyzed in a 5:1 water-soil solution.

\subsection{Statistical Analyses}

Data were analyzed using SPSS software (v. 16.0, Chicago, IL, USA) with an accepted significance level of $\alpha=0.05$. One-way analysis of variance (ANOVA) and a post hoc Duncan's multiple-range test were performed to determine the significant differences between the soil properties from different $\mathrm{N}$ addition treatments. A nonmetric multidimensional scaling (NMDS) ordination to illustrate the clustering of bacterial and fungal community composition variation was conducted on the Bray-Curtis distance of the order. Pearson's correlation coefficients between diversity indices and soil microbial functional group abundance, as well as soil microbial community diversity indices, were calculated. Redundancy analyses (RDA) were conducted on soil chemical properties with microbial diversity; specific bacteria and fungi were analyzed separately. RDA analyses were conducted with CANOCO 5.0 software (Beijing, China).

\section{Results}

\subsection{Soil Chemical Properties}

Soil TC content was found to be in the range of $388.57 \mathrm{mg} \cdot \mathrm{g}^{-1}$ to $406.53 \mathrm{mg} \cdot \mathrm{g}^{-1}$. TC content was lower in the N3 treatment than in N1, N2, and CK treatments. DOC content in all treatments ranged from $331.00 \mathrm{mg} \cdot \mathrm{kg}^{-1}$ to $566.47 \mathrm{mg} \cdot \mathrm{kg}^{-1}$. DOC content in the N1 treatment was higher than in $\mathrm{CK}, \mathrm{N} 2$, and N3 treatments (Table 1). TN content ranged 
from $14.07 \mathrm{mg} \cdot \mathrm{g}^{-1}$ to $24.70 \mathrm{mg} \cdot \mathrm{g}^{-1}$ in the all treatments, and TN in N1 and N3 treatments was lower than in the N2 treatment. Furthermore, AN content ranged from $39.94 \mathrm{mg} \cdot \mathrm{kg}^{-1}$ to $123.41 \mathrm{mg} \cdot \mathrm{kg}^{-1}$, and $\mathrm{NN}$ content ranged from $34.01 \mathrm{mg} \cdot \mathrm{kg}^{-1}$ to $55.06 \mathrm{mg} \cdot \mathrm{kg}^{-1}$ in all treatments. AN was higher in the N1 treatment than in CK, N2, and N3 treatments. Furthermore, NN was higher in N1 and N2 treatments than in CK and N3 treatments. TP content ranged from $1.41 \mathrm{mg} \cdot \mathrm{g}^{-1}$ to $1.98 \mathrm{mg} \cdot \mathrm{g}^{-1}$ in all treatments. TP decreased significantly with the increase in $\mathrm{N}$ addition (Table 1). Soil $\mathrm{pH}$ values ranged from 5.73 to 5.83 , and they did not vary significantly with the addition of different amounts of $\mathrm{N}$ (Table 1).

Table 1. Effects of nitrogen addition on the content of soil carbon, nitrogen and phosphorus. Values are means \pm standard error $(n=3)$. TC: total carbon; TN: total nitrogen; TP: total phosphorus; AN: ammonium nitrogen; NN: nitrate nitrogen; DOC: dissolved organic carbon. CK: $0 \mathrm{~g} \mathrm{~N} \cdot \mathrm{m}^{-2} \cdot$ year $^{-1}$; $\mathrm{N} 1: 6 \mathrm{~g} \mathrm{~N} \cdot \mathrm{m}^{-2} \cdot$ year $^{-1}$; N2: $12 \mathrm{~g} \mathrm{~N} \cdot \mathrm{m}^{-2} \cdot \mathrm{year}^{-1} ; \mathrm{N} 3: 24 \mathrm{~g} \mathrm{~N} \cdot \mathrm{m}^{-2} \cdot \mathrm{year}^{-1}$. Different letters indicate a significant difference among different concentrations of nitrogen addition treatments $(p<0.05)$ as estimated by one-way ANOVA and a post hoc Duncan's multiple-range test.

\begin{tabular}{|c|c|c|c|c|c|c|c|}
\hline & $\begin{array}{c}\mathrm{TC} \\
\left(\mathrm{mg} \cdot \mathrm{g}^{-1}\right)\end{array}$ & $\begin{array}{c}\mathrm{TN} \\
\left(\mathrm{mg} \cdot \mathrm{g}^{-1}\right)\end{array}$ & $\begin{array}{c}\mathrm{TP} \\
\left(\mathrm{mg} \cdot \mathrm{g}^{-1}\right)\end{array}$ & $\begin{array}{c}\mathrm{AN} \\
\left(\mathrm{mg} \cdot \mathrm{kg}^{-1}\right)\end{array}$ & $\begin{array}{c}\mathrm{NN} \\
\left(\mathrm{mg} \cdot \mathrm{kg}^{-1}\right)\end{array}$ & $\begin{array}{c}\text { DOC } \\
\left(\mathrm{mg} \cdot \mathrm{kg}^{-1}\right)\end{array}$ & $\mathrm{pH}$ \\
\hline CK & $403.23 \pm 12.77 \mathrm{a}$ & $14.07 \pm 1.08 c$ & $1.98 \pm 0.01 \mathrm{a}$ & $39.94 \pm 9.48 c$ & $45.75 \pm 17.22 \mathrm{ab}$ & $421.53 \pm 91.65 \mathrm{ab}$ & $5.73 \pm 0.02 a$ \\
\hline N1 & $406.53 \pm 2.53 a$ & $18.28 \pm 0.62 b$ & $1.79 \pm 0.29 \mathrm{ab}$ & $123.41 \pm 1.13 a$ & $55.06 \pm 0.82 a$ & $566.47 \pm 63.89 a$ & $5.76=$ \\
\hline N2 & $392.89 \pm 10.55 a$ & $24.70 \pm 1.09 a$ & $1.70 \pm 0.12 \mathrm{ab}$ & $46.56 \pm 5.76 c$ & $53.82 \pm 2.44 \mathrm{ab}$ & $331.00 \pm 15.51 b$ & $5.75 \pm 0.20 \mathrm{a}$ \\
\hline N3 & $388.57 \pm 9.92 \mathrm{a}$ & $16.90 \pm 1.22 b$ & $1.41 \pm 0.20 \mathrm{~b}$ & $95.81 \pm 10.57 \mathrm{~b}$ & $34.01 \pm 0.19 b$ & $351.33 \pm 87.57 \mathrm{~b}$ & $5.83 \pm 0.06 a$ \\
\hline
\end{tabular}

\subsection{Soil Microbial Functional Group Abundance}

Abundances of bacteria, fungi, archaea, nif $\mathrm{H}, \mathrm{b}-a m o \mathrm{~A}$, denitrification genes (nir $\mathrm{K}$, nirS), mcr A, and pmoA were determined using RT-PCR analysis. In all four $\mathrm{N}$ addition treatments, bacterial abundance $\left(3.71 \times 10^{12}\right.$ copies. $\mathrm{g}^{-1}$ to $5.36 \times 10^{12}$ copies. $\mathrm{g}^{-1}$ dry soil $)$ was more higher than fungal abundance $\left(7.44 \times 10^{9}\right.$ copies. ${ }^{-1}$ to $4.92 \times 10^{10}$ copies. ${ }^{-1}$ dry soil) and archaeal abundance $\left(3.10 \times 10^{8}\right.$ copies. ${ }^{-1}$ to $9.92 \times 10^{9}$ copies. ${ }^{-1}$ dry soil $)$ (Figure 1). Compared with CK, the abundances of bacteria, fungi, and archaea were higher in $\mathrm{N}$ addition treatments and highest in the $\mathrm{N} 2$ treatment. In addition, the abundances of nif $\mathrm{H}, \mathrm{b}-$ amo $\mathrm{A}$ and morA were higher in $\mathrm{N}$ addition treatment groups than in CK (Figure 1). The abundance of nirK tended to increase with the increase in $\mathrm{N}$ addition level, but this increase was not significant (Figure 1).

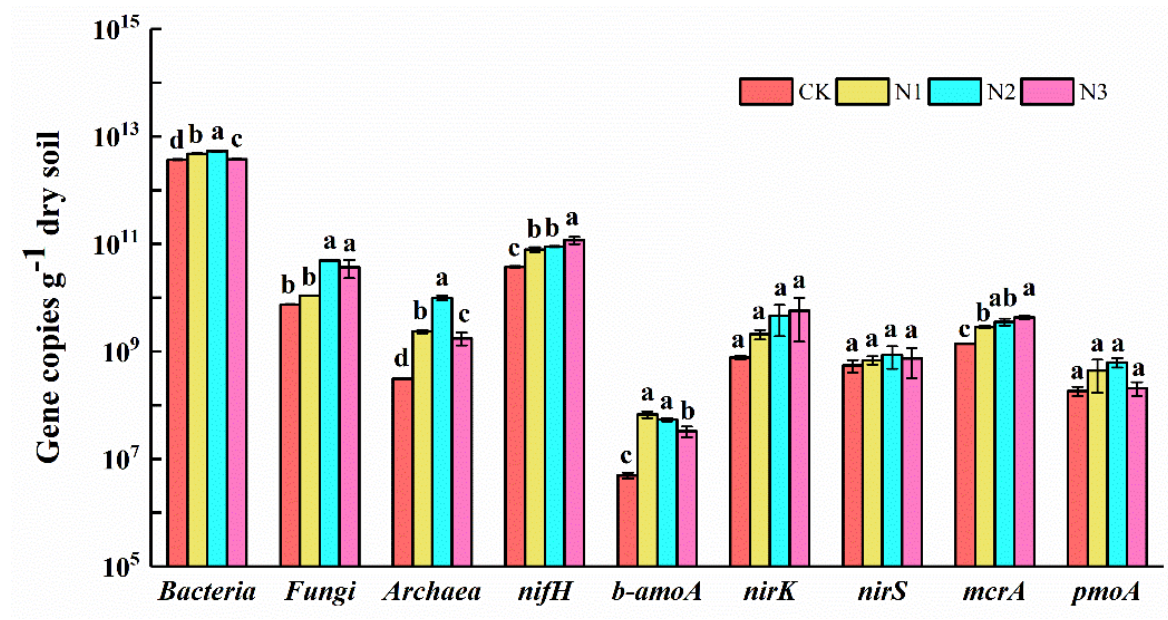

Figure 1. The effect of nitrogen addition on soil microbial functional gene abundance in permafrost peatland. CK: $0 \mathrm{~g} \mathrm{~N} \cdot \mathrm{m}^{-2} \cdot$ year $^{-1}$; $\mathrm{N} 1: 6 \mathrm{~g} \mathrm{~N} \cdot \mathrm{m}^{-2} \cdot$ year $^{-1}$; $\mathrm{N} 2: 12 \mathrm{~g} \mathrm{~N} \cdot \mathrm{m}^{-2} \cdot$ year $^{-1}$; $\mathrm{N} 3: 24 \mathrm{~g} \mathrm{~N} \cdot \mathrm{m}^{-2} \cdot$ year $^{-1}$. Different letters indicate a significant difference among different concentrations of nitrogen addition treatments $(p<0.05)$ as estimated by one-way ANOVA and a post hoc Duncan's multiple-range test. 


\subsection{Soil Microbial Community Composition and Diversity}

In the CK plot, the dominant bacterial phyla were Actinobacteria $(22.81 \%)$ and Acidobacteria (21.45\%), followed by Proteobacteria (18.05\%), Chloroflexi $(9.6 \%)$, Bacteroidota (8.26\%), Verrucomicrobiota (4.62\%), Desulfobacterota (2.88\%), Patescibacteria (2.52\%), Myxococcota $(1.44 \%)$, Firmicutes $(1.04 \%)$, Gemmatimonadota $(0.91 \%)$, Nitrospirota $(0.88 \%)$, and Planctomycetota $(1.14 \%)$ (Figure 2a). Actinobacteria was the most dominant bacterial phylum in all $\mathrm{N}$ addition treatments. The Proteobacteria relative abundance in the N2 treatment was significantly higher than that in N1 and N3 treatments. However, the relative abundances of Actinobacteria and Verrucifera in the N2 treatment and Patescibacteria in the $\mathrm{N} 1$ treatment were significantly lower than in the N3 treatment (Figure 2a). In the CK plot, the dominant fungal community was Ascomycota (49.89\%), followed by Basidiomycota (44.31\%), Mortierellomycota (1.41\%), unclassified-k-Fungi (2.91\%), Rozellomycota (1.16\%), Chytridiomycota $(1.06 \%)$, and Monoblepharomycota $(0.21 \%)$. Ascomycota was the most dominant fungal phylum in all $\mathrm{N}$ addition treatments. The abundance of Basidiomycota decreased, while the abundances of Mortierellomycota and Rozellomycota increased with the increase in $\mathrm{N}$ addition amount. However, no significant differences were observed across the fungal phyla in different $\mathrm{N}$ addition treatments (Figure $2 \mathrm{~b}$ ).

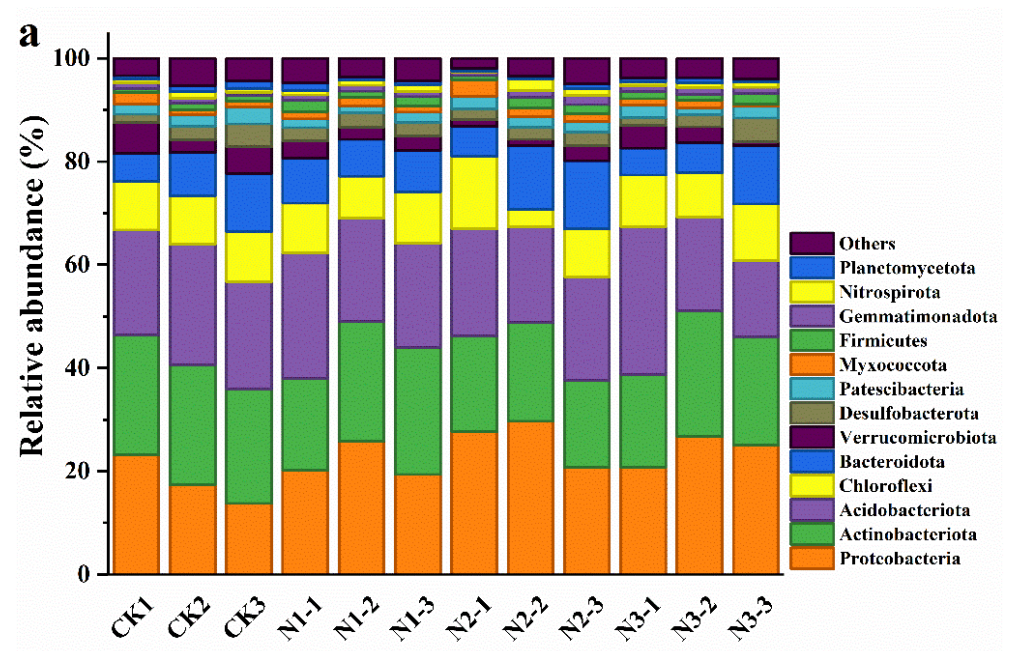

b

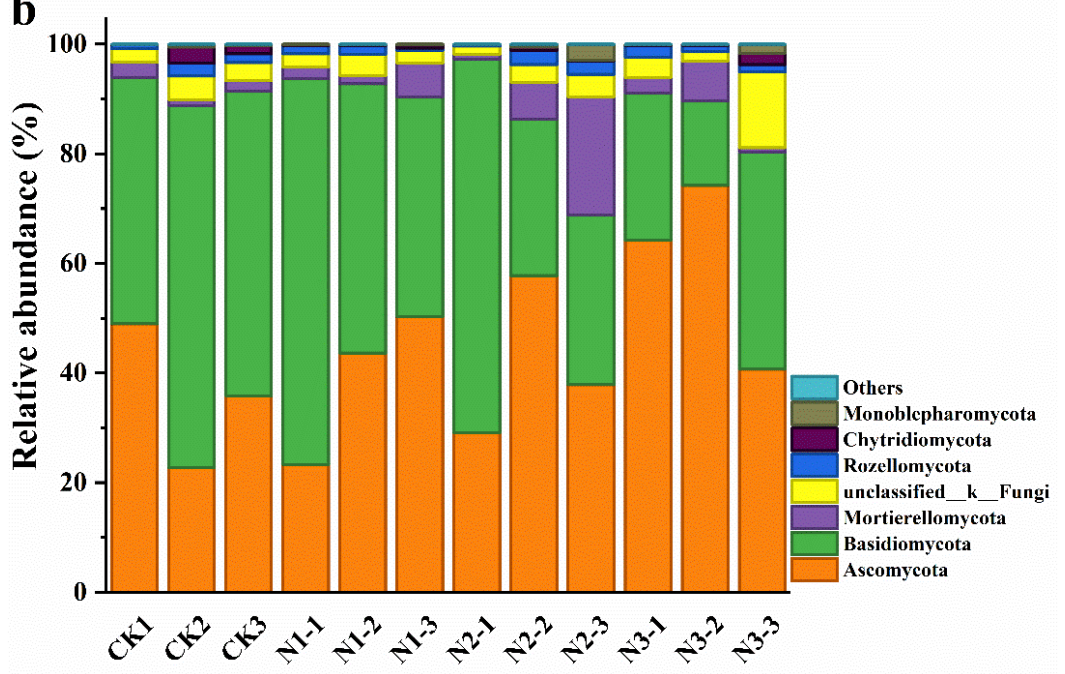

Figure 2. The effect of nitrogen addition on relative abundances of (a) bacteria phyla and (b) fungi phyla. Displayed are phyla with $>1 \%$ relative abundance. Unclassified bacterial and fungal phyla $<1 \%$ abundance were grouped as "others". CK1, CK2, CK3: $0 \mathrm{~g} \mathrm{~N} \cdot \mathrm{m}^{-2} \cdot \mathrm{year}^{-1}$; N1-1, N1-2, N1-3: $6 \mathrm{~g} \mathrm{~N} \cdot \mathrm{m}^{-2} \cdot$ year $^{-1}$; N2-1, N2-2, N2-3: $12 \mathrm{~g} \mathrm{~N} \cdot \mathrm{m}^{-2} \cdot$ year $^{-1}$; N3-1, N3-2, N3-3: $24 \mathrm{~g} \mathrm{~N} \cdot \mathrm{m}^{-2} \cdot$ year $^{-1}$. 
NMDS analysis based on Bray-Curtis similarity distance of order showed that the composition of soil bacteria in N1, N2, and N3 treatments clustered more closely together than in the CK treatment (Figure 3a), and fungal composition in CK, N1, and N2 treatments clustered more closely together (Figure $3 b$ ). The heatmap graphically showed that the order of soil bacterial and fungal communities differed with $\mathrm{N}$ addition treatment, which supported the NMDS analyses (Figure 4). We observed that the composition of soil bacterial dominant order in N1, N2, N3, and CK treatments were different. The relative abundances of Solibacterales, Pedosphaerales, and Corynebacteriales were highest in the CK treatment and lowest in N3, N2, and N1 treatments, respectively; there was a significant difference in abundance between $\mathrm{CK}$ and different $\mathrm{N}$ addition treatments $(p<0.05)$ (Figure $4 \mathrm{a})$. Furthermore, the dominant order composition of soil fungi was different between CK and N3 treatments. Compared with the CK treatment, the relative abundance of unclassified_P_Mortierellomycota, Coniochaetales, and unclassified_c_Monoblepharidomycetes showed significant differences under N3 treatment $(p<0.01)$ (Figure $4 b)$.
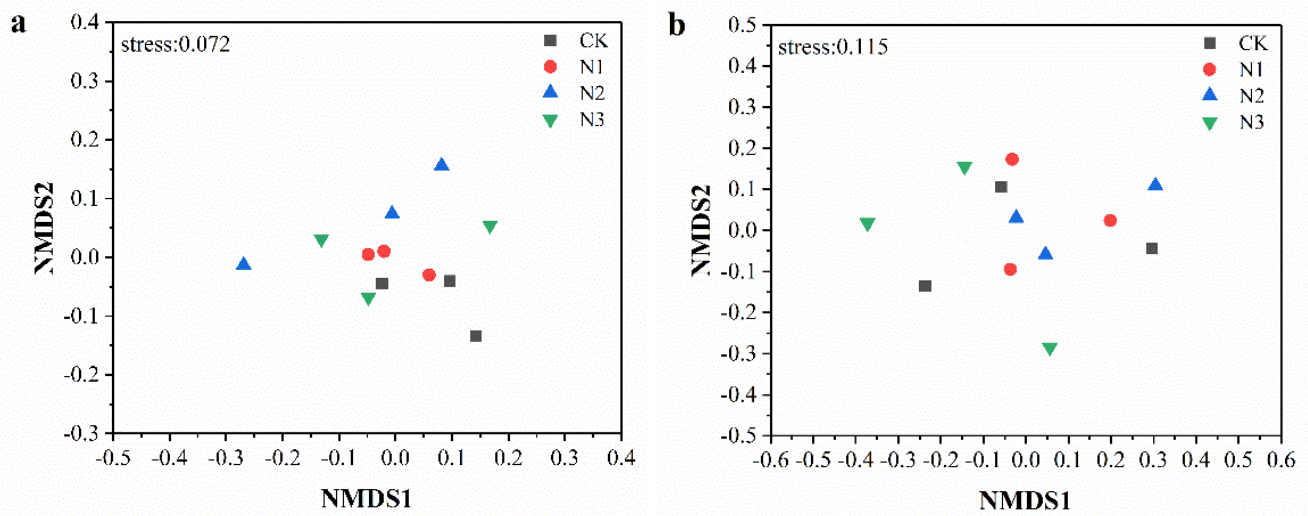

Figure 3. NMDS ordination based on Bray-Curtis similarities of (a) bacterial and (b) fungal communities under nitrogen addition. CK: $0 \mathrm{~g} \mathrm{~N} \cdot \mathrm{m}^{-2} \cdot$ year $^{-1} ; \mathrm{N} 1: 6 \mathrm{~g} \mathrm{~N} \cdot \mathrm{m}^{-2} \cdot$ year $^{-1}$; $\mathrm{N} 2: 12 \mathrm{~g} \mathrm{~N} \cdot \mathrm{m}^{-2} \cdot$ year $^{-1}$; N3: $24 \mathrm{~g} \mathrm{~N} \cdot \mathrm{m}^{-2} \cdot$ year $^{-1}$.

The Shannon, Simpson, Ace, and Chao indices were used to estimate and compare the alpha diversity of bacterial and fungal communities in N1, N2, and N3. We observed that Ace and Chao indices of bacteria in N1 treatment were significantly higher than in CK and differed significantly between N1 and CK treatments (Figure 5C,D). The Simpson index of fungi in the N1 treatment was significantly higher than in CK, N2, and N3 treatments (Figure 6B).

\subsection{The Relationship between Soil Microorganisms and Soil Chemical Properties under Nitrogen Addition}

Correlation analysis of microbial abundance and soil chemical properties showed that the abundances of bacteria, fungi, archaea, and b-amoA were significantly and positively correlated to TN. The abundance of b-amoA was significantly and positively correlated to AN (Table 2). Moreover, the relative abundances of Proteobacteria $(r=0.792$, $p<0.01)$, Actinobacteria $(r=0.589, p<0.05)$, Bacteroidota $(r=0.659, p<0.05)$, Myxococcota $(r=0.620, p<0.05)$, and Gemmatimonadota $(\mathrm{r}=0.668, p<0.05)$ were positively correlated to TN (Figure 7a). The relative abundance of Ascomycota was negatively correlated to $\operatorname{TP}(r=-0.674, p<0.05)$. The relative abundances of Basidiomycota $(r=0.696, p<0.05)$, Mortierellomycota $(r=0.605, p<0.05)$, and Rozellomycota $(r=0.687, p<0.05)$ were positively correlated to TN. The relative abundance of Mortierellomycota was negatively correlated to $\mathrm{pH}(r=-0.673, p<0.05)$. The relative abundance of unclassified-k-Fungi was negatively correlated to TC $(r=-0.787, p<0.01)$. The relative abundance of Monoblepharomycota was negatively correlated to TC and $\mathrm{pH}(r=-0.590, p<0.05 ; r=-0.673$, $p<0.05$ ) (Figure 7b). 

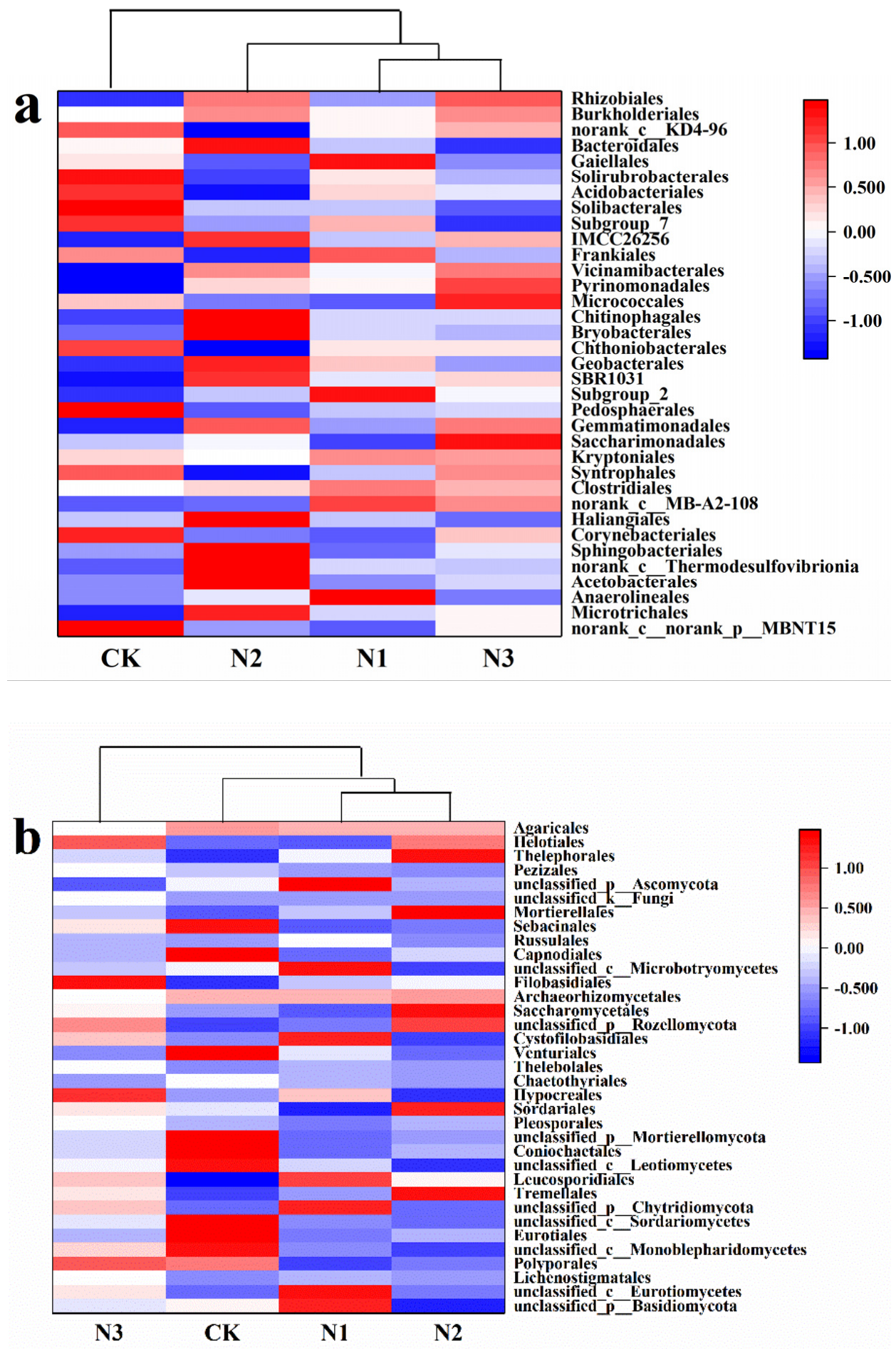

Figure 4. The relative abundances of (a) bacteria and (b) fungi order with the first 35 most abundant genera were made into a clustering heat map. CK: $0 \mathrm{~g} \mathrm{~N} \cdot \mathrm{m}^{-2} \cdot$ year $^{-1} ; \mathrm{N} 1: 6 \mathrm{~g} \mathrm{~N} \cdot \mathrm{m}^{-2} \cdot$ year $^{-1}$; $\mathrm{N} 2: 12 \mathrm{~g} \mathrm{~N} \cdot \mathrm{m}^{-2} \cdot$ year $^{-1} ; \mathrm{N} 3: 24 \mathrm{~g} \mathrm{~N} \cdot \mathrm{m}^{-2} \cdot$ year $^{-1}$. 


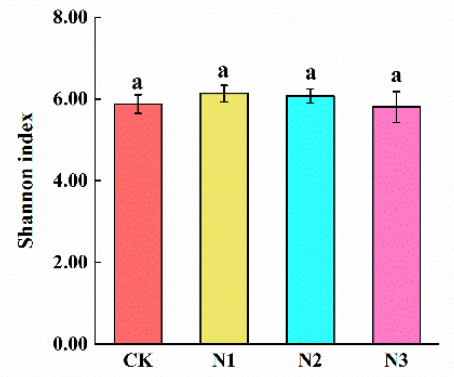

(A)

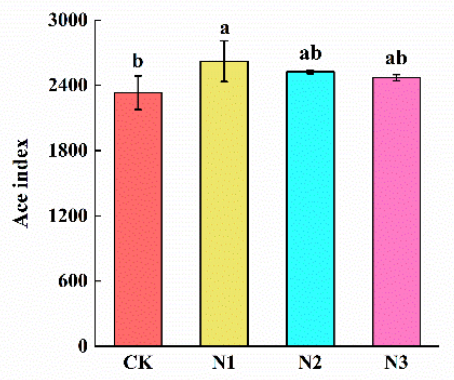

(C)

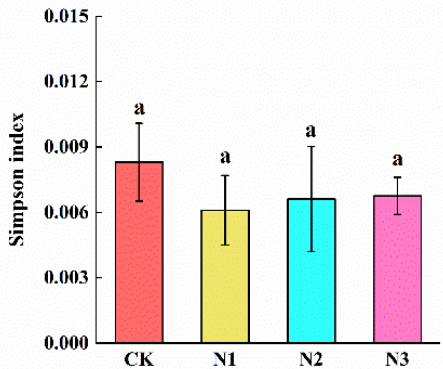

(B)

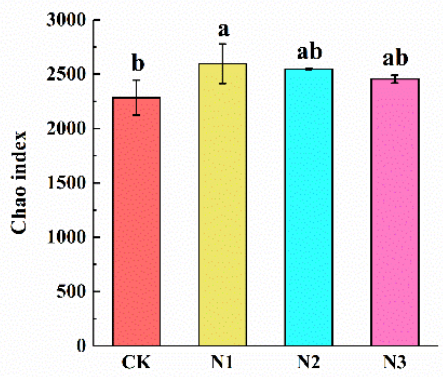

(D)

Figure 5. The alpha diversity of soil bacteria under nitrogen addition treatment. CK: $0 \mathrm{~g} \quad \mathrm{~N} \cdot \mathrm{m}^{-2} \cdot \mathrm{year} \mathrm{r}^{-1}$; $\mathrm{N} 1: 6 \mathrm{~g} \mathrm{~N} \cdot \mathrm{m}^{-2} \cdot$ year $^{-1}$; N2: $12 \mathrm{~g} \mathrm{~N} \cdot \mathrm{m}^{-2} \cdot$ year $^{-1}$; N3: $24 \mathrm{~g} \mathrm{~N} \cdot \mathrm{m}^{-2} \cdot$ year $^{-1}$. (A): Shannon index; (B): Simpson index; (C): Ace index; (D): Chao index. Different letters indicate a significant difference among different concentrations of nitrogen addition treatments $(p<0.05)$ as estimated by one-way ANOVA and the subsequent Duncan's multiple-range test.

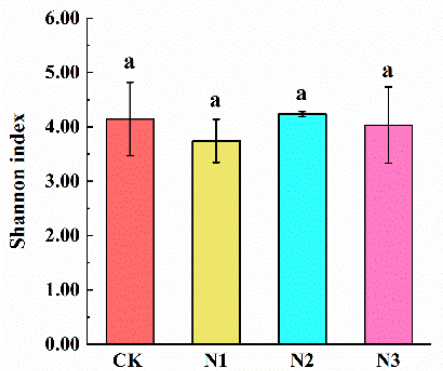

(A)

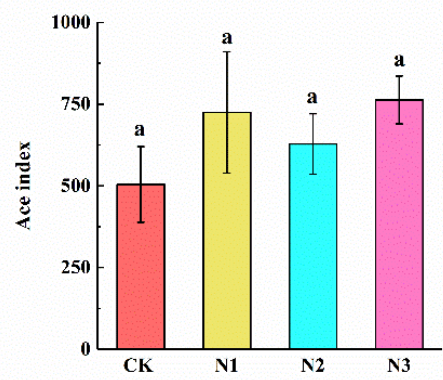

(C)

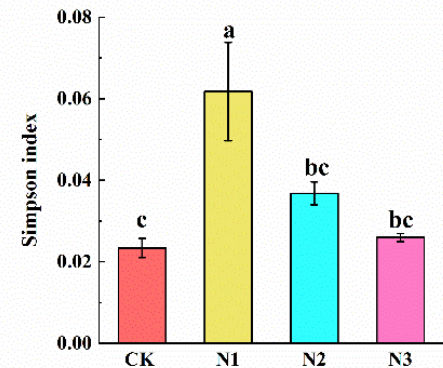

(B)

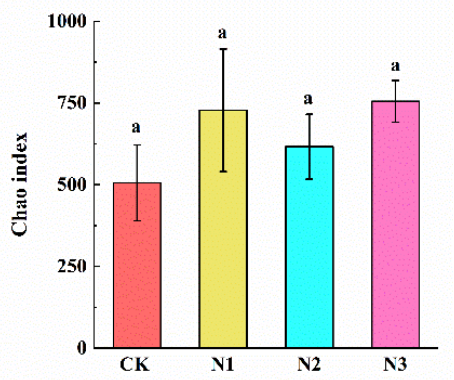

(D)

Figure 6. The alpha diversity of soil fungi under nitrogen addition treatment. CK: $0 \mathrm{~g} \mathrm{~N} \cdot \mathrm{m}^{-2} \cdot \mathrm{year}^{-1} ; \mathrm{N} 1: 6 \mathrm{~g} \mathrm{~N} \cdot \mathrm{m}^{-2} \cdot \mathrm{year}^{-1}$; N2: $12 \mathrm{~g} \mathrm{~N} \cdot \mathrm{m}^{-2} \cdot$ year $^{-1}$; N3: $24 \mathrm{~g} \mathrm{~N} \cdot \mathrm{m}^{-2} \cdot$ year $^{-1}$. (A): Shannon index; (B): Simpson index; (C): Ace index; (D): Chao index. Different letters indicate a significant difference among different concentrations of nitrogen addition treatments $(p<0.05)$ as estimated by one-way ANOVA and a post hoc Duncan's multiple-range test. 
Table 2. Pearson correlation analysis of soil microbial abundance and soil chemical properties. TC: total carbon; TN: total nitrogen; TP: total phosphorus; AN: ammonium nitrogen; NN: nitrate nitrogen; DOC: dissolved organic carbon. ${ }^{*}$ significant at the 0.05 level, ${ }^{* *}$ significant at the 0.01 level. Bold text indicates statistically significant correlations.

\begin{tabular}{|c|c|c|c|c|c|c|c|c|c|c|c|c|c|c|c|c|}
\hline Indicator & Bacteria & Fungi & Archaea & $n i f \mathbf{H}$ & B-amo $A$ & nirK & nirS & $m c r \mathbf{A}$ & pmoA & TC & TN & TP & AN & NN & DOC & $\mathrm{pH}$ \\
\hline Bacteria & 1 & & & & & & & & & & & & & & & \\
\hline Fungi & 0.42 & 1 & & & & & & & & & & & & & & \\
\hline Archaea & $0.85 * *$ & $0.75^{* *}$ & 1 & & & & & & & & & & & & & \\
\hline nif $\mathrm{H}$ & 0.17 & $0.68^{*}$ & 0.30 & 1 & & & & & & & & & & & & \\
\hline B-amoA & $0.75^{* *}$ & 0.31 & 0.51 & 0.46 & 1 & & & & & & & & & & & \\
\hline nirK & 0.14 & $0.73^{* *}$ & 0.36 & $0.73^{* *}$ & 0.27 & 1 & & & & & & & & & & \\
\hline nirs & 0.31 & 0.48 & 0.35 & 0.44 & 0.28 & $0.78^{* *}$ & 1 & & & & & & & & & \\
\hline$m c r A$ & 0.26 & $0.73^{* *}$ & 0.41 & $0.94^{* *}$ & 0.48 & $0.74 * *$ & 0.47 & 1 & & & & & & & & \\
\hline pmoA & $0.81 * *$ & 0.42 & 0.65 * & 0.19 & 0.61 * & 0.13 & 0.21 & 0.22 & 1 & & & & & & & \\
\hline TC & -0.05 & -0.36 & -0.24 & -0.45 & 0.11 & -0.35 & -0.25 & -0.55 & 0.11 & 1 & & & & & & \\
\hline $\mathrm{TN}$ & $0.86 * *$ & $0.75^{* *}$ & $0.92 * *$ & 0.36 & 0.63 * & 0.35 & 0.42 & 0.47 & 0.70 & -0.13 & 1 & & & & & \\
\hline TP & 0.08 & -0.52 & -0.09 & -0.55 & -0.25 & -0.44 & -0.20 & -0.26 & 0.34 & 0.28 & -0.28 & 1 & & & & \\
\hline AN & -0.01 & -0.17 & -0.30 & 0.43 & 0.58 * & 0.10 & -0.02 & 0.36 & -0.04 & 0.22 & -0.09 & -0.32 & 1 & & & \\
\hline $\mathrm{NN}$ & 0.49 & -0.10 & 0.33 & -0.26 & 0.40 & -0.22 & 0.10 & -0.28 & 0.19 & 0.18 & 039 & 0.13 & 0.02 & 1 & & \\
\hline DOC & 0.02 & -0.44 & -0.35 & -0.19 & 0.37 & -0.10 & 0.11 & -0.67 & 0.07 & $0.74 * *$ & 0.18 & 0.23 & 0.56 & 0.36 & 1 & \\
\hline $\mathrm{pH}$ & -0.18 & 0.03 & -0.17 & 0.18 & 0.04 & -0.38 & -0.53 & 0.04 & 0.04 & 0.12 & -0.04 & -0.30 & 0.15 & -0.13 & -0.13 & 1 \\
\hline
\end{tabular}
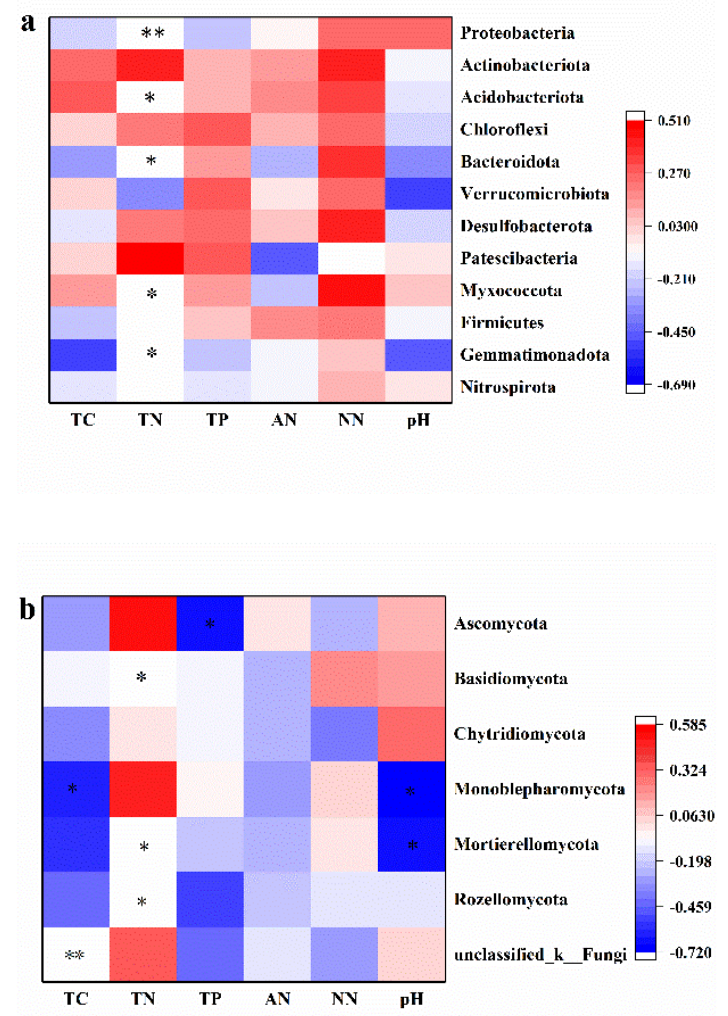

Figure 7. Correlation analysis of soil microbial relative abundance at (a) bacteria and (b) fungi phyla level and soil chemical properties under nitrogen addition. * significant at 0.05 level, ${ }^{* *}$ significant at 0.01 level.

The RDA of soil chemical properties and alpha diversity indices of microbial community in all $\mathrm{N}$ treatments is shown in Figure 8. The Shannon index of bacteria was positively correlated to TC, TN, DOC, AN, and NN; however, the Simpson index of bacteria was negatively correlated to TC, TN, DOC, AN, and NN. The Shannon index of bacteria was negatively correlated to TP and $\mathrm{pH}$, and the Simpson index of bacteria positively correlated to TP and $\mathrm{pH}$. Ace and Chao indices of bacteria were positively correlated to TN, DOC, AN, pH, and NN, but negatively correlated to TC and TP. With $23.9 \%, 20.6 \%$, and $15.4 \%$ contribution rates, $\mathrm{AN}, \mathrm{TN}$, and TC contributed remarkably to bacterial diversity, respectively (Figure 8a). The Shannon index of fungi was positively correlated to TC and 
TN, but negatively correlated to AN, NN, DOC, and $\mathrm{pH}$. Simpson, Ace, and Chao indices of fungi were positively correlated to $\mathrm{AN}, \mathrm{NN}, \mathrm{DOC}$, and $\mathrm{pH}$, but negatively correlated to TP. The contribution rates of AN and TP to fungal diversity indices were $56.7 \%$ and $29.3 \%$, respectively (Figure 8b).
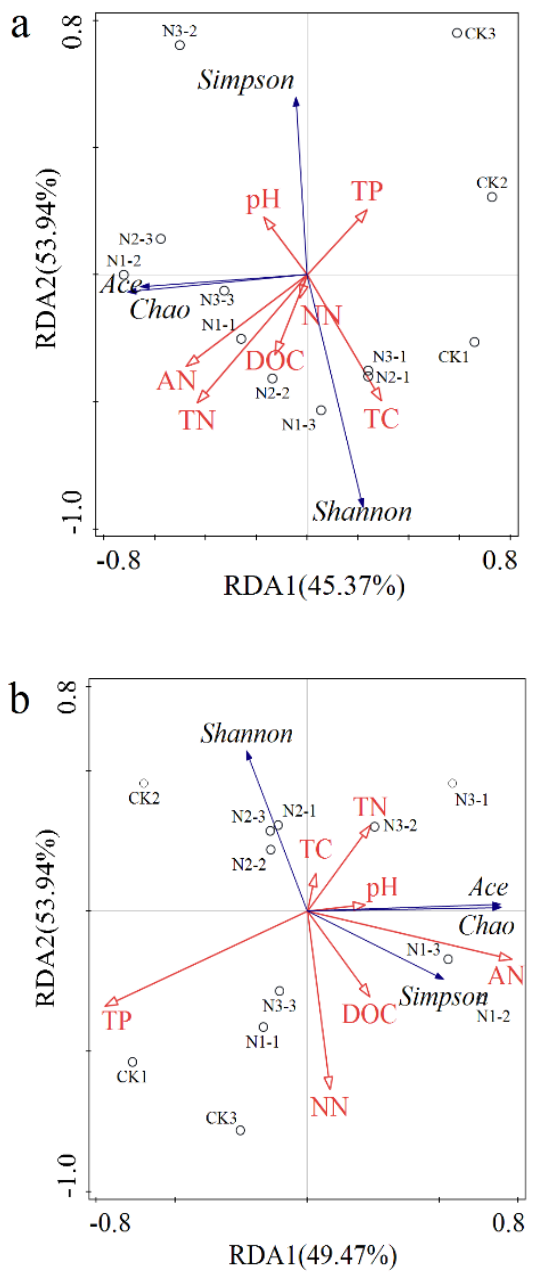

Figure 8. Redundancy analysis (RDA) of soil chemical properties and the alpha diversity indices of (a) bacteria and (b) fungi microbial communities under nitrogen addition treatments. TC: total carbon; $\mathrm{TN}$ : total nitrogen; TP: total phosphorus; AN: ammonium nitrogen; NN: nitrate nitrogen; DOC: dissolved organic carbon. CK1, CK2, CK3: $0 \mathrm{~g} \mathrm{~N} \cdot \mathrm{m}^{-2} \cdot \mathrm{year}^{-1}$; N1-1, N1-2, N1-3: $6 \mathrm{~g} \mathrm{~N} \cdot \mathrm{m}^{-2} \cdot$ year $^{-1}$; $\mathrm{N} 2-1, \mathrm{~N} 2-2, \mathrm{~N} 2-3: 12 \mathrm{~g} \mathrm{~N} \cdot \mathrm{m}^{-2} \cdot$ year $^{-1}$; N3-1, N3-2, N3-3: $24 \mathrm{~g} \mathrm{~N} \cdot \mathrm{m}^{-2} \cdot$ year $^{-1}$. The red arrows and blue arrows represent soil chemical properties and the alpha diversity indices of bacteria and fungi microbial communities, respectively.

\section{Discussion}

\subsection{Effect of $N$ Addition on Soil Microbial Functional Gene Abundance in Permafrost Peatland}

Soil microbes contribute significantly to all the biogeochemical processes of soil $[12,13]$, such as soil carbon mineralization, methane production and oxidation, $\mathrm{N}$ fixation, and nitrification or denitrification [40]. The change of nutrient environment can affect the key microbes related to soil $\mathrm{C}$ and $\mathrm{N}$ cycles in different directions and to different degrees. Our observations supported our hypothesis that the microbial abundance in the soil of permafrost peatlands increased under $\mathrm{N}$ addition. Compared with control, the abundances of bacteria, fungi, archaea, nif $\mathrm{H}, \mathrm{b}-a m o \mathrm{~A}$, and $m c r \mathrm{~A}$ were higher in $\mathrm{N}$ addition treatments. In line with our hypothesis, soil nif $\mathrm{H}$ (increased $110 \%$ to $213 \%$ ) and b-amoA (increased $567 \%$ to $1262 \%$ ) abundances in permafrost peatland were more sensitive to $\mathrm{N}$ addition than agricultural soils (nif H: no effect; b-amoA: increased 313\%) according to a meta-analysis 
result of 47 field studies [41]. However, contrary to our hypothesis, soil nirK (no effect) and nirS (no effect) genes were less sensitive to $\mathrm{N}$ addition in permafrost peatland than in agricultural soils, increasing $53 \%$ and $40 \%$, respectively [41]. The abundances of bacteria, fungi, archaea, $\mathrm{b}$-amoA, and $m c r \mathrm{~A}$ were found to increase under $\mathrm{N}$ addition, indicating that $\mathrm{N}$ addition may promote microbial decomposition of soil organic matter, ammonia oxidation, $\mathrm{N}$ fixation, and methane production. Previous studies have also demonstrated that the abundances of bacteria, fungi, archaea [42], and b-amoA [43] increased with $\mathrm{N}$ addition. Orr et al. [44] showed that $\mathrm{N}$ addition increased the abundance of $\mathrm{N}$-fixing bacteria and promoted the $\mathrm{N}$-fixing function of soil microbes in cropland. In line with the findings of our study, $\mathrm{N}$ addition induced an increase in abundance of nif $\mathrm{H}$ in Antarctic soils [45]. The response of nif $\mathrm{H}$ to different levels of $\mathrm{N}$ addition was different, related to the cultivar and the amount of added N [46]. As reported previously, Juraeva et al. [47] found that the relative abundance of the nif $\mathrm{H}$ gene pool in plant roots was positively correlated with $\mathrm{N}$ supply. Coelho et al. [48] also found that a low concentration of $\mathrm{N}$ input could improve the nif $\mathrm{H}$ gene abundance in the rhizosphere of sorghum bicolor. We previously found that $\mathrm{N}$ addition could increase the biomass of plant roots in the same $\mathrm{N}$ addition plots [49]. Therefore, $\mathrm{N}$ addition could improve nif $\mathrm{H}$ abundance by promoting plant root growth and secreting more exudates. In contrast, Tian et al. [50] demonstrated that $\mathrm{N}$ addition decreased the abundance of $\mathrm{N}$-fixing bacteria in forest ecosystems. $\mathrm{N}$ addition did not have a significant effect on nirK gene abundance in permafrost peatland soil. Previous researchers have also obtained consistent results suggesting that nitrite reductase (NO-forming) is insensitive to environmental changes [51]. Wang et al. [18] reported that $\mathrm{N}$ addition induced a decrease in the abundances of soil bacteria and fungi in subtropical forest, which might have been associated with the significant decrease in soil $\mathrm{pH}$. A lower soil $\mathrm{pH}$ could trigger aluminum toxicity, hampering microbial growth [52]. However, in the current study, as $\mathrm{N}$ addition did not induce significant soil acidification, we concluded that $\mathrm{pH}$ may be not the major regulatory factor for soil microbial abundance in permafrost peatlands.

\subsection{Effects of N Addition on Soil Microbial Community Composition and Diversity in Permafrost Peatland}

The community structure and diversity of soil microorganisms respond distinctly to different $\mathrm{N}$ addition levels [53]. At the phylum level, the relative abundances of bacteria showed different trends in response to different $\mathrm{N}$ addition levels. $\mathrm{N}$ addition could alter microbial community composition [54], resulting in the altered relative abundance of specific bacteria phyla [55]. Compared with CK, N1, and N3 treatments, the relative abundance of Proteobacteria in the N2 treatment was highest. Proteobacteria, which comprise eutrophic bacteria, grow and reproduce rapidly in high-N environments [16]. Moreover, $\mathrm{N}$ addition decreased the relative abundances of Acidobacteria and Verrucifera. Furthermore, the relative abundances of Actinobacteria and Verrucifera in the N2 treatment were significantly lower than in CK. In line with the findings of our study, $\mathrm{N}$ addition induced a decrease in the abundances of Actinobacteria and Verrucifera in the topsoil of subtropical acidic forests [56]. The plausible reason might be that Actinobacteria and Verrucifera belong to the oligotrophic group, and their lower growth rate makes them more suitable for soil conditions with lower nutrient levels [16]. Additionally, these microbes have a lower ability to use carbon sources in a high-N environment [57]. We observed that Ascomycota was the most dominant fungal phylum. In line with a previous study by Zhu et al. [58], the abundance of Basidiomycota decreased, whereas the abundances of Mortierellomycota and Rozellomycota increased with the $\mathrm{N}$ addition amount. The soil bacterial dominant orders in different $\mathrm{N}$ addition and $\mathrm{CK}$ treatments were different, while the dominant order composition of soil fungi in the CK treatment was different to that in the N3 treatment. The relative increases or decreases in abundance of soil microorganisms with the availability of nitrogen may be due to $\mathrm{N}$ addition directly or indirectly leading to the transformation of lifecycle strategies of major microorganisms; thus, their response to 
$\mathrm{N}$ addition is inconsistent $[16,59]$. The altered structure and composition of soil microbial community in the $\mathrm{N}$ addition reflected the altered nutrient absorption [60].

Consistent with our initial hypothesis, $\mathrm{N}$ addition increased the bacterial and fungal diversity, but this depended on the $\mathrm{N}$ addition level. We observed that $\mathrm{N} 1$ treatment increased the Ace and Chao indices of bacteria and the Simpson index of fungi in permafrost peatlands. Li et al. [23] also reported that $\mathrm{N}$ addition increased fungal diversity and differentially affected microbial community composition and structure by modifying microbial preferences in alpine meadows soil. However, these positive effects were different from the results of previous studies, which reported that $\mathrm{N}$ addition reduced the bacterial Chao1 index in agricultural grassland and forests soils $[56,61]$ and the fungal Simpson index in forests soils [62]. Furthermore, as reported previously, $\mathrm{N}$ addition decreased bacterial richness by decreasing soil $\mathrm{pH}$; thus, $\mathrm{N}$ addition negatively affected soil microbial communities in forest soils $[18,63]$. However, in the current study, the soil $\mathrm{pH}$ did not change significantly, suggesting that the altered soil microbial diversity was closely correlated with soil nutrients, but little correlated with soil $\mathrm{pH}$ under $\mathrm{N}$ addition in permafrost peatlands. Under the condition of long-term $\mathrm{N}$ addition, the composition of the soil microbial community may be altered, but the soil $\mathrm{pH}$ did not change significantly [64,65]. The results showed that the responses of the Simpson index of fungi to $\mathrm{N}$ addition were more sensitive than those of the Simpson index of bacteria. This finding is in line with Yang et al. [66], who showed that soil fungal diversity was more sensitive than soil bacterial diversity under global $\mathrm{N}$ addition, because soil fungi had a higher carbon and nutrient assimilation efficiency than soil bacteria.

\subsection{Effects of Soil Chemical Properties on the Soil Microorganisms under Nitrogen Addition in Permafrost Peatland}

$\mathrm{N}$ addition could alter soil properties directly or indirectly by affecting soil microbial communities [63]. We observed that DOC decreased in N2 and N3 treatments, which might have been due to $\mathrm{N}$ addition-induced increase in the soil labile carbon decomposition $[28,67]$. High levels of $\mathrm{N}$ addition decreased soil DOC concentrations, indicating that soil active organic $\mathrm{C}$, an energy source for microbial growth, responded to $\mathrm{N}$ addition. These changes are most likely because $\mathrm{N}$ addition stimulated the growth of microorganisms and changed C-use efficiency due to the exhaustion of active C substrates [68]. Fang et al. [69] reported that the decrease in DOC concentration in soil was a consequence of changing microbial decomposition and humidification processes. Soil TP content significantly decreased in the N3 treatment due to the increase in absorption and utilization of TP by plants in a high- $\mathrm{N}$ environment $[28,67]$, limiting $\mathrm{P}$ availability compared to $\mathrm{N}$ [23]. The integrated effect of soil organic carbon stimulation resulted in no significant effect on TC in different $\mathrm{N}$ addition treatments. $\mathrm{N}$ addition promoted the decomposition of active organic $\mathrm{C}$. On the other hand, $\mathrm{N}$ addition provided more $\mathrm{N}$ nutrition for plant growth, improved plant productivity, and increased the carbon input of plant litter, resulting in an unclear change in soil TC content [68]. However, current studies on soil carbon sequestration potential under $\mathrm{N}$ addition-driven conditions are divergent [70]. $\mathrm{N}$ input significantly stimulated an increase in soil carbon level in some ecosystems [71] but a significant decrease in others [72] or remained constant [73], depending on ecosystem types and $\mathrm{N}$ addition level.

We analyzed soil microbial functional gene abundance and diversity along with soil chemical properties in different $\mathrm{N}$ addition treatments. The outcomes suggested that bacterial, archaeal, and b-amoA abundances were closely related to $\mathrm{TN}$, and that soil $\mathrm{N}$ is a major factor regulating the abundances of soil bacteria, archaea, and b-amoA [74,75]. We also observed that Proteobacteria, Actinobacteria, Bacteroidota, Myxococcota, Gemmatimonadota, Basidiomycota, Mortierellomycota, and Rozellomycota were correlated to TN, whereas Ascomycota was correlated to TP. This indicates that $\mathrm{N}$ addition influenced soil microbial community structure by altering soil nutrient level. 


\section{Conclusions}

This study demonstrated that continued $\mathrm{N}$ addition for nine growing seasons increased the abundances of bacteria, fungi, archaea, nif $\mathrm{H}, \mathrm{b}-a m o \mathrm{~A}$, and $m c r \mathrm{~A}$ in permafrost peatland, indicating that $\mathrm{N}$ addition could stimulate the decomposition of soil organic matter, oxidation of ammonia, fixation of $\mathrm{N}$, nitrification, and production of methane, thereby affecting soil $\mathrm{C}$ and $\mathrm{N}$ cycling. Soil nif $\mathrm{H}$ and $\mathrm{b}$-amoA abundances in permafrost were more sensitive to $\mathrm{N}$ addition than agricultural soils, but nirK and nirS abundances were less sensitive to $\mathrm{N}$ addition in peatland soil than in agricultural soils. N3 treatment changed the dominant order composition of soil fungi. In addition, N1 treatment increased the Ace and Chao indices of bacteria and the Simpson index of fungi. The positive effects of $\mathrm{N}$ addition on diversity indices of soil bacteria and fungi were different from grassland and forests soils, indicating that soil microbial diversity was closely correlated with soil nutrients but not soil $\mathrm{pH}$ under $\mathrm{N}$ addition in permafrost peatlands. The results highlight the important role of microbes in regulating soil ecological processes in permafrost peatlands under $\mathrm{N}$ addition. This study focused only on the effects of $\mathrm{N}$ addition on belowground microbial processes; thus, future studies should explore the interaction and response mechanism of aboveground plants and soil microbes to $\mathrm{N}$ addition.

Supplementary Materials: The following are available online at https:/ / www.mdpi.com/article/ 10.3390/microorganisms9122498/s1, Table S1: PCR primers and amplification details used for the amplification of functional targets.

Author Contributions: Conceptualization, Y.S., C.S., X.W. and X.M.; methodology, Y.S. and C.S.; investigation, X.W., N.W., S.G., X.C., Z.L., J.G. and Y.D.; writing-original draft preparation, X.M. and Y.S.; writing-review and editing, all.; funding acquisition, Y.S. and C.S. All authors have read and agreed to the published version of the manuscript.

Funding: This work was supported by the National Natural Science Foundation of China (41871090; 41730643), the Science and Technology Development Program of Jilin Province of China (20210101091JC), and the Strategic Priority Research Program of the Chinese Academy of Sciences (No. XDA28020502).

Institutional Review Board Statement: Not applicable.

Informed Consent Statement: Not applicable.

Data Availability Statement: Data are available on request.

Conflicts of Interest: The authors declare no conflict of interest.

\section{References}

1. $\quad$ Elser, J.J.; Bracken, M.E.S.; Cleland, E.E.; Gruner, D.S.; Harpole, W.S.; Hillebrand, H.; Ngai, J.T.; Seabloom, E.W.; Shurin, J.B.; Smith, J.E. Global analysis of nitrogen and phosphorus limitation of primary producers in freshwater, marine and terrestrial ecosystems. Ecol. Lett. 2007, 10, 1135-1142. [CrossRef] [PubMed]

2. Xie, D.Z.; Zhao, B.; Wang, S.; Lei, D. Benefit of China's reduction in nitrogen oxides emission to natural ecosystems in East Asia with respect to critical load exceedance. Environ. Int. 2020, 136, 105468. [CrossRef]

3. Liu, X.J.; Zhang, Y.; Han, W.X.; Tang, A.H.; Shen, J.L.; Cui, Z.L.; Vitousek, P.; Erisman, J.W.; Goulding, K.; Christie, P.; et al. Enhanced nitrogen deposition over China. Nature 2013, 494, 459-462. [CrossRef]

4. Galloway, J.N.; Townsend, A.R.; Erisman, J.W.; Bekunda, M.; Cai, Z.; Freney, J.R.; Martinelli, L.A.; Seitzinger, S.P.; Sutton, M.A. Transformation of the nitrogen cycle: Recent trends, questions, and potential solutions. Science 2008, 320, 889-892. [CrossRef] [PubMed]

5. Lamarque, J.F.; Kiehl, J.T.; Brasseur, G.P.; Butler, T.; Cameron-Smith, P.; Collins, W.D.; Collins, W.J.; Granier, C.; Hauglustaine, D.; Hess, P.G.; et al. Assessing future nitrogen deposition and carbon cycle feedback using a multimodel approach: Analysis of nitrogen deposition. J. Geophys. Res. Atmos. 2005, 110, D19303. [CrossRef]

6. Contribution of Working Groups I, II, and III to the Fourth Assessment Report of the Intergovernmental Panel on Climate Change. In Proceedings of the IPCC Climate Change 2014: Synthesis Report, Geneva, Switzerland, 1 November 2014.

7. Tian, H.Q.; Melillo, J.; Lu, C.Q.; Kicklighter, D.; Liu, M.L.; Ren, W.; Xu, X.F.; Chen, G.S.; Zhang, C.; Pan, S.F.; et al. China's terrestrial carbon balance: Contributions from multiple global change factors. Glob. Biogeochem. Cycles 2011, 25, GB1007. [CrossRef]

8. Xia, Z.; Yang, J.; Sang, C.; Wang, X.; Bai, E. Phosphorus reduces negative effects of nitrogen addition on soil microbial communities and functions. Microorganisms 2020, 8, 1828. [CrossRef] 
9. Craig, H.; Antwis, R.E.; Cordero, I.; Ashworth, D.; Robinson, C.H.; Osborne, T.Z.; Bardgett, R.D.; Rowntree, J.K.; Simpson, L.T. Nitrogen addition alters composition, diversity, and functioning of microbial communities in mangrove soils: An incubation experiment. Soil Biol. Biochem. 2021, 153, 108076. [CrossRef]

10. Wang, C.; Liu, D.; Bai, E. Decreasing soil microbial diversity is associated with decreasing microbial biomass under nitrogen addition. Soil Biol. Biochem. 2018, 120, 126-133. [CrossRef]

11. Bassiri, R.H. Consequences of atmospheric nitrogen deposition in terrestrial ecosystems, old questions, new perspectives. Oecologia 2015, 177, 1-3. [CrossRef]

12. Damashek, J.; Francis, C.A. Microbial nitrogen cycling in Estuaries: From genes to ecosystem processes. Estuaries Coasts 2018, 41, 626-660. [CrossRef]

13. Huang, L.; Riggins, C.W.; Rodríguez-Zas, S.; Zabaloy, M.C.; Villamil, M.B. Long-term N fertilization imbalances potential N acquisition and transformations by soil microbes. Sci. Total Environ. 2019, 691, 562-571. [CrossRef]

14. Li, H.; Xu, Z.; Yang, S.; Li, X.; Top, E.M.; Wang, R.; Zhang, Y.; Cai, J.; Yao, F.; Han, X.; et al. Response of soil bacterial communities to nitrogen deposition and precipitation increment are closely linked with aboveground communtiy variation. Microb. Ecol. 2016, 71, 974-989. [CrossRef]

15. Zhang, X.L.; Zhang, Q.Q.; Yang, A.J.; Hou, L.J.; Zheng, Y.L.; Zhai, W.D.; Gong, J. Incorporation of microbial functional traits in biogeochemistry models provides better estimations of benthic denitrification and anammox rates in coastal oceans. Biogeosciences 2018, 12, 3331-3352. [CrossRef]

16. Fierer, N.; Lauber, C.L.; Ramirez, K.S.; Zaneveld, J.; Bradford, M.A.; Knight, R. Comparative metagenomic, phylogenetic and physiological analyses of soil microbial communities across nitrogen gradients. ISME J. 2012, 6, 1007-1017. [CrossRef]

17. Zheng, S.; Bian, H.; Quan, Q.; Xu, L.; Chen, Z.; He, N. Effect of nitrogen and acid deposition on soil respiration in a temperate forest in China. Geoderma 2018, 329, 82-90. [CrossRef]

18. Wang, J.Q.; Shi, X.Z.; Zheng, C.Y.; Suter, H.; Huang, Z.Q. Different responses of soil bacterial and fungal communities to nitrogen deposition in a subtropical forest. Sci. Total Environ. 2021, 755, 142449. [CrossRef]

19. Zhang, J.Y.; Ai, Z.M.; Liang, C.T.; Wang, G.L.; Xue, S. Response of soil microbial communities and nitrogen thresholds of Bothriochloa ischaemum to short-term nitrogen addition on the Loess Plateau. Geoderma 2017, 308, 112-119. [CrossRef]

20. van der Bom, F.; Nunes, I.; Raymond, N.S.; Hansen, V.; Bonnichsen, L.; Magid, J.; Nybroe, O.; Jensen, L.S. Long-term fertilisation form, level and duration affect the diversity, structure and functioning of soil microbial communities in the field. Soil Biol. Biochem. 2018, 122, 91-103. [CrossRef]

21. Ouyang, Y.; Norton, J.M. Short-term nitrogen fertilization affects microbial community composition and nitrogen mineralization functions in an agricultural soil. Appl. Environ. Microbiol. 2020, 86, e02278-e02319. [CrossRef]

22. Tang, H.M.; Li, C.; Xiao, X.P.; Shi, L.H.; Cheng, K.K.; Wen, L.; Li, W.W. Effects of short-term manure nitrogen input on soil microbial community structure and diversity in a double-cropping paddy field of southern China. Sci. Rep. 2020, 10, 13540. [CrossRef] [PubMed]

23. Li, J.H.; Cheng, B.H.; Zhang, R.; Li, W.J.; Shi, X.M.; Wei, H.Y.; Ye, L.F.; Ostle, N.J.; Bardgett, R.D. Nitrogen and phosphorus additions accelerate decomposition of slow carbon pool and lower total soil organic carbon pool in alpine meadows. Land Degrad. Dev. 2021, 32, 1761-1772. [CrossRef]

24. Shi, X.Z.; Wang, J.Q.; Müller, C.; Hu, H.W.; He, J.Z.; Wang, J.T.; Huang, Z.Q. Dissimilatory nitrate reduction to ammonium dominates soil nitrate retention capacity in subtropical forests. Biol. Fertil. Soils 2020, 56, 785-797. [CrossRef]

25. Moore, T.R.; Bubier, J.L. Plant and soil Nitrogen in an ombrotrophic peatland, Southern Canada. Ecosystems 2020, 23, 98-110. [CrossRef]

26. Salmon, V.G.; Brice, D.J.; Bridgham, S.; Childs, J.; Graham, J.; Griffiths, N.A.; Hofmockel, K.; Iversen, C.M.; Jicha, T.M.; Kolka, R.K.; et al. Nitrogen and phosphorus cycling in an ombrotrophic peatland: A benchmark for assessing change. Plant Soil 2021, 466, 649-674. [CrossRef]

27. Waldrop, M.P.; Zak, D.R.; Sinsabaugh, R.L.; Gallo, M.; Lauber, C. Nitrogen deposition modifies soil carbon storage through changes in microbial enzymatic activity. Ecol. Appl. 2004, 14, 1172-1177. [CrossRef]

28. Mack, M.C.; Schuur, E.A.G.; Bret-Harte, M.S.; Shaver, G.R.; Chapin, F.S. Ecosystem carbon storage in arctic tundra reduced by long-term nutrient fertilization. Nature 2004, 431, 440-443. [CrossRef]

29. Gong, Y.; Wu, J.H.; Vogt, J.; Le, T.B. Warming reduces the increase in $\mathrm{N}_{2} \mathrm{O}$ emission under nitrogen fertilization in a boreal peatland. Sci. Total Environ. 2019, 664, 72-78. [CrossRef]

30. Miao, Y.; Song, C.; Sun, L.; Wang, X.; Meng, H.; Mao, R. Growing season methane emission from a boreal peatland in the continuous permafrost zone of Northeast China: Effects of active layer depth and vegetation. Biogeosciences 2012, 9, 4455-4464. [CrossRef]

31. Zhang, Z.; Schwartz, S.; Wagner, L.; Miller, W. A greedy algorithm for aligning DNA sequences. J. Comput. Biol. 2000, 7, $203-214$. [CrossRef]

32. Xu, N.; Tan, G.; Wang, H.; Gai, X. Effect of biochar additions to soil on nitrogen leaching, microbial biomass and bacterial community structure. Eur. J. Soil Biol. 2016, 74, 1-8. [CrossRef]

33. Adams, R.I.; Miletto, M.; Taylor, J.W.; Bruns, T.D. Dispersal in microbes: Fungi in indoor air are dominated by outdoor air and show dispersal limitation at short distances. ISME J. 2013, 7, 1262-1273. [CrossRef] 
34. Magoč, T.; Salzberg, S. FLASH: Fast length adjustment of short reads to improve genome assemblies. Bioinformatics 2011, 27, 2957-2963. [CrossRef]

35. Caporaso, J.G.; Kuczynski, J.; Stombaugh, J.; Bittinger, K.; Bushman, F.D.; Costello, E.K.; Fierer, N.; Peña, A.G.; Goodrich, J.K.; Gordon, J.I.; et al. QIIME allows analysis of high-throughput community sequencing data. Nat. Methods 2010, 7, 335-336. [CrossRef]

36. Rognes, T.; Flouri, T.; Nichols, B.; Quince, C.; Mahé, F. Vsearch: A versatile open source tool for metagenomics. Peer J. 2016, 4, e2584. [CrossRef]

37. Edgar, R.C. Search and clustering orders of magnitude faster than BLAST. Bioinformatics 2010, 26, 2460-2461. [CrossRef]

38. Wang, Q.; Garrity, G.M.; Tiedje, J.M.; Cole, J.R. Naive bayesian classifier for rapid assignment of rRNA sequences into the new bacterial taxonomy. Appl. Environ. Microbiol. 2007, 73, 5261-5267. [CrossRef]

39. Ghani, A.; Dexter, M.; Perrott, K.W. Hot-water extractable carbon in soils: A sensitive measurement for determining impacts of fertilization, grazing and cultivation. Soil Biol. Biochem. 2003, 35, 1231-1243. [CrossRef]

40. Xiao, Z.; Rasmann, S.; Yue, L.; Lian, F.; Zou, H.; Wang, Z. The effect of biochar amendment on N-cycling genes in soils: A meta-analysis. Sci. Total Environ. 2019, 696, 133984. [CrossRef]

41. Yang, O.; Evans, S.E.; Friesen, M.L.; Tiemann, L.K. Effect of nitrogen fertilization on the abundance of nitrogen cycling genes in agricultural soils: A meta-analysis of field studies. Soil Biol. Biochem. 2018, 127, 71-78. [CrossRef]

42. Wang, Q.; Ma, M.; Jiang, X.; Guan, D.; Wei, D.; Zhao, B.; Chen, S.; Cao, F.; Li, L.; Yang, X. Impact of 36 years of nitrogen fertilization on microbial community composition and soil carbon cycling-related enzyme activities in rhizospheres and bulk soils in northeast China. Appl. Soil Ecol. 2019, 136, 148-157. [CrossRef]

43. Ai, C.; Liang, G.; Sun, J.; Wang, X.; He, P.; Zhou, W. Different roles of rhizosphere effect and long-term fertilization in the activity and community structure of ammonia oxidizers in a calcareous fluvo-aquic soil. Soil Biol. Biochem. 2013, 57, 30-42. [CrossRef]

44. Orr, C.H.; Leifert, C.; Cummings, S.P.; Cooper, J.M. Impacts of organic and conventional crop management on diversity and activity of free-living nitrogen fixing bacteria and total bacteria are subsidiary to temporal effects. PLoS ONE 2012, 7, e52891. [CrossRef] [PubMed]

45. Jung, J.; Yeom, J.; Kim, J.; Han, J.; Lim, H.S.; Park, H. Change in gene abundance in the nitrogen biogeochemical cycle with temperature and nitrogen addition in antarctic soils. Res. Microbiol. 2011, 162, 1018-1026. [CrossRef]

46. Marcia, R.R.C.; Ivanildo, E.M.; Sasha, N.J.; Clare, V.L.; Lucy, S.; Anthony, G.O. Molecular detection and quantification of nifH gene sequences in the rhizosphere of sorghum (sorghum bicolor) sown with two levels of nitrogen fertilizer. Appl. Soil Ecol. 2009, $42,48-53$.

47. Juraeva, D.; George, E.; Davranov, K.; Ruppel, S. Detection and quantification of the nifH gene in shoot and root of cucumber plants. Can. J. Microbiol. 2006, 52, 731-739. [CrossRef]

48. Coelho, M.R.R.; de Vos, M.; Carneiro, N.P.; Marriel, I.E.; Paiva, E.; Seldin, L. Diversity of nifH gene pools in the rhizosphere of two cultivars of sorghum (Sorghum bicolor) treated with contrasting levels of nitrogen fertilizer. FEMS Microbiol. Lett. 2008, 279, 15-22. [CrossRef]

49. Gao, J.L.; Song, Y.Y.; Song, C.C.; Zhang, H.; Tan, W.W.; Du, Y. Effects of different concentrations of nitrogen additions on fine root morphological characteristics in permafrost peatland in the Daxing'an Mountains. Acta Ecol. Sinica 2021, 41, 8171-8177.

50. Tian, J.; Dungait, J.A.J.; Lu, X.K.; Yang, Y.F.; Hartley, I.P.; Zhang, W.; Mo, J.M.; Yu, G.R.; Zhou, J.Z.; Kuzyakov, Y. Long-term nitrogen addition modifies microbial composition and functions for slow carbon cycling and increased sequestration in tropical forest soil. Glob. Change Biol. 2019, 25, 3267-3281. [CrossRef]

51. Zhang, W.; Zhu, X.; Liu, L.; Fu, S.; Chen, H. Large difference of inhibitive effect of nitrogen deposition on soil methane oxidation between plantations with N-fixing tree species and non-N-fixing tree species. J. Geophys Res.-Biogeo. 2012, 117, G00N16. [CrossRef]

52. Drabek, O.; Boruvka, L.; Mladkova, L.; Kocarek, M. Possible method of aluminium speciation in forest soils. J. Inorg. Biochem. 2003, 97, 8-15. [CrossRef]

53. Zhang, Y.; Loreau, M.; He, N.; Zhang, G.; Han, X. Mowing exacerbates the loss of ecosystem stability under nitrogen enrichment in a temperate grassland. Funct. Ecol. 2017, 31, 1637-1646. [CrossRef] [PubMed]

54. Freedman, Z.B.; Romanowicz, K.J.; Upchurch, R.A.; Zak, D.R. Differential responses of total and active soil microbial communities to long-term experimental N deposition. Soil Biol. Biochem. 2015, 90, 275-282. [CrossRef]

55. Turlapati, S.A.; Minocha, R.; Bhiravarasa, P.S.; Tisa, L.S.; Thomas, W.K.; Minocha, S.C. Chronic N-amended soils exhibit an altered bacterial community structure in Harvard Forest, MA, USA. FEMS Microbiol. Ecol. 2012, 83, 478-493. [CrossRef]

56. Cui, J.Y.; Yuan, X.C.; Zhang, Q.F.; Zhou, J.C.; Lin, K.M.; Xu, J.G.; Zeng, Y.Z.; Wu, Y.; Cheng, L.; Zeng, Q.X.; et al. Nutrient availability is a dominant predictor of soil bacterial and fungal community composition after nitrogen addition in subtropical acidic forests. PLoS ONE 2021, 16, e0246263. [CrossRef]

57. Craine, J.M.; Morrow, C.; Fierer, N. Microbial nitrogen limitation increases decomposition. Ecology 2007, 88, 2105-2113. [CrossRef]

58. Zhu, X.C.; Sun, L.Y.; Song, F.B.; Liu, S.Q.; Liu, F.L.; Li, X.N. Soil microbial community and activity are affected by integrated agricultural practices in China. Eur. J. Soil Sci. 2018, 69, 924-935. [CrossRef]

59. Lu, G.R.; Xie, B.H.; Cagle, G.A.; Wang, X.H.; Han, G.X.; Wang, X.J.; Hou, A.X.; Guan, B. Effects of simulated nitrogen deposition on soil microbial community diversity in coastal wetland of the Yellow River Delta. Sci. Total Environ. 2021, 757, 143825. [CrossRef]

60. Li, Y.B.; Bezemer, T.M.; Yang, J.J.; Lü, X.T.; Li, X.Y.; Liang, W.J.; Han, X.G.; Li, Q. Changes in litter quality induced by N deposition alter soil microbial communities. Soil Biol. Biochem. 2019, 130, 33-42. [CrossRef] 
61. Freitag, T.E.; Chang, L.; Clegg, C.D.; Prosser, J.I. Influence of inorganic nitrogen management regime on the diversity of nitrite-oxidizing bacteria in agricultural grassland soils. Appl. Environ. Microbiol. 2005, 71, 8323-8334. [CrossRef]

62. Frey, S.D.; Knorr, M.; Parrent, J.L.; Simpson, R.T. Chronic nitrogen enrichment affects the structure and function of the soil microbial community in temperate hardwood and pine forests. For. Ecol. Manag. 2004, 196, 159-171. [CrossRef]

63. Shi, X.Z.; Hu, H.W.; Wang, J.; He, J.Z.; Zheng, C.; Wan, X.; Huang, Z. Niche separation of comammox Nitrospira and canonical ammonia oxidizers in an acidic subtropical forest soil under long-term nitrogen deposition. Soil Biol. Biochem. 2018, 126, 114-122. [CrossRef]

64. Kirchmann, H.; Schön, M.; Börjesson, G.; Hamnér, K.; Kätterer, T. Properties of soils in the Swedish long-term fertility experiments: VII. Changes in topsoil and upper subsoil at Örja and Fors after 50 years of nitrogen fertilization and manure application. Acta Agric. Scand. Sect. B-Soil Plant Sci. 2013, 63, 25-36. [CrossRef]

65. Geisseler, D.; Scow, K.M. Long-term effects of mineral fertilizers on soil microorganisms-A review. Soil Biol. Biochem. 2014, 75, 54-63. [CrossRef]

66. Yang, Y.; Cheng, H.; Gao, H.; An, S.S. Response and driving factors of soil microbial diversity related to global nitrogen addition. Land Degrad. Dev. 2020, 31, 190-204. [CrossRef]

67. Zeglin, L.H.; Stursova, M.; Sinsabaugh, R.L.; Collins, S.L. Microbial responses to nitrogen addition in three contrasting grassland ecosystems. Oecologia 2007, 154, 349-359. [CrossRef]

68. Song, Y.; Song, C.; Meng, H.; Swarzenski, C.M.; Wang, X.; Tan, W. Nitrogen additions affect litter quality and soil biochemical properties in a peatland of northeast china. Ecol. Eng. 2017, 100, 175-185. [CrossRef]

69. Fang, H.J.; Cheng, S.L.; Yu, G.R.; Xu, M.J.; Wang, Y.S.; Li, L.S.; Dang, X.S.; Wang, L.; Li, Y.N. Experimental nitrogen deposition alters the quantity and quality of soil dissolved organic carbon in an alpine meadow on the Qinghai-Tibetan Plateau. Appl. Soil Ecol. 2014, 81, 1-11. [CrossRef]

70. Deng, L.; Huang, C.; Kim, D.; Shangguan, Z.; Wang, K.; Song, X.; Peng, C. Soil GHG fluxes are altered by N deposition: New data indicate lower $\mathrm{N}$ stimulation of the $\mathrm{N}_{2} \mathrm{O}$ flux and greater stimulation of the calculated C pools. Glob. Chang. Biol. 2020, 26, 2613-2629. [CrossRef]

71. Guan, B.; Xie, B.H.; Yang, S.S.; Hou, A.X.; Chen, M.; Han, G.X. Effects of five years' nitrogen deposition on soil properties and plant growth in a salinized reed wetland of the Yellow River Delta. Ecol. Eng. 2019, 136, 160-166. [CrossRef]

72. Song, C.; Liu, D.; Yang, G.; Song, Y.; Mao, R. Effect of nitrogen addition on decomposition of Calamagrostis angustifolia litters from freshwater marshes of northeast China. Ecol. Eng. 2011, 37, 1578-1582. [CrossRef]

73. Jiang, C.M.; Yu, G.R.; Fang, H.J.; Cao, G.M.; Li, Y.N. Short-term effect of increasing nitrogen deposition on $\mathrm{CO}_{2}, \mathrm{CH}_{4}$ and $\mathrm{N}_{2} \mathrm{O}$ fluxes in an alpine meadow on the Qinghai-Tibetan Plateau, China. Atmos. Environ. 2010, 44, 2920-2926. [CrossRef]

74. Zhou, J.; Guan, D.; Zhou, B.; Zhao, B.; Ma, M.; Qin, J.; Jiang, X.; Chen, S.; Cao, F.; Shen, D.; et al. Influence of 34-years of fertilization on bacterial communities in an intensively cultivated black soil in northeast China. Soil Biol. Biochem. 2015, 90, 42-51. [CrossRef]

75. Wang, Q.; Jiang, X.; Guan, D.; Wei, D.; Zhao, B.; Ma, M.; Chen, S.; Li, L.; Cao, F.; Li, J. Long-term fertilization changes bacterial diversity and bacterial communities in the maize rhizosphere of Chinese Mollisols. Appl. Soil Ecol. 2018, 125, 88-96. [CrossRef] 